\title{
Effects of Canopy Management and Fruit Thinning on Seed Quality of Tomato (Solanum lycopersicum L.) Variety Thilina
}

\author{
C.K. Pathirana*, I.D.C. Sajeevika ${ }^{1}$, P.R.S. Pathirana ${ }^{2}$, H. Fonseka ${ }^{3}$ and R.M. Fonseka ${ }^{4}$ \\ Postgraduate Institute of Agriculture \\ University of Peradeniya \\ Sri Lanka
}

\begin{abstract}
Tomato (Solanum lycopersicum L.) is a commonly grown vegetable crop in Sri Lanka. As in many other vegetables, lack of good quality seeds is a major constraint in tomato cultivation as there is a deficiency in technologies to obtain high quality seeds under Sri Lankan farming conditions. Therefore, the present study was conducted to find a suitable method of canopy management and fruit cluster pruning for high seed quality. Tomato variety Thilina was used for the experiment and plants were established in a replicated field trial. Three levels of cluster pruning and canopy management were employed namely,; no pruning and fruit thinning, pruning with thinning up to 2 fruits/cluster and 5 fruit clusters per plant, pruning with thinning up to 5 fruits/cluster and 5 fruit clusters per plant. Treatments were evaluated in terms of fruit yield, seed purity, 1000 seed weight, seed germination, seed viability and seedling vigour. Pruning with thinning up to 2 fruits/cluster and 5 fruit clusters per plant yielded larger fruits compared to the fruits produced by the other plants. Pruning along with fruit thinning had increased the seed weight compared to the control treatment. The cluster pruning had no advantage on seed germination however, seedling vigour was greatly benefited. The highest shoot length was observed in pruning with thinning up to 2 fruits/cluster and 5 fruit clusters per plant compared to other treatments. The results revealed that canopy management and fruit thinning are good practices for improving the seedling vigour of the resultant seeds.
\end{abstract}

Keywords: Canopy management, cluster pruning, fruit thinning, Solanum lycopersicum, seed quality

\section{INTRODUCTION}

Tomato (Solanum lycopersicum L.) is an important vegetable crop which belongs to the family Solanaceae. It is the second most important vegetable crop in the world and the total world production of tomato is 153 million tons (Anon, 2009). Tomato is an annual crop often cultivates in open fields both in temperate and tropical regions. The land extent under tomato in Sri Lanka is approximately 7614 ha and the average yield is about 10 t/ha (Anon, 2010). Tomato cultivation must be highly productive, competitive and efficient in resource use to become a sustainable venture. Production of good quality tomato seed is important to boost tomato cultivation. Physically and genetically pure and viable seeds are crucial to stand establishment of tomato which would lead to a higher fruit yield.

\footnotetext{
Faculty of Agricultural Sciences, Sabaragamuwa University of Sri Lanka, Belihuloya, Sri Lanka

Faculty of Science, University of Colombo, Sri Lanka

Horticultural Crop Research and Development Institute, Peradeniya, Sri Lanka

4 Department of Crop Science, Faculty of Agriculture, University of Peradeniya, Sri Lanka.

Corresponding author: ckpathirana0421@gmail.com
} 
In general, tomato fruits are harvested in 8 - 10 picks. Except the first and the last fruit harvests, the remaining fruits are used for seed extraction. Seeds from middle picks are higher in vigour and in percentage germination. Small fruits and pest and disease infested fruits must be removed from the lot and only graded fruits are taken for seed extraction purpose. Seed viability depends on the method used to extract seeds (http://agritech.tnau.ac.in/seed_certification).

Although initial seed quality depends on genetic characteristics, some of the important seed quality parameters such as seed germination, seedling emergence and seed weight are also determined by the performances of the mother plant. Amount of dry matter accumulation determines the seed weight, and it is also a crucial factor to increase the seed vigour. Since seed germination and seedling emergence are highly energy required plant processes, seed weight is an essential factor to consider as it provides storage food for generating energy for this purpose (Tabasi et al., 2011). The fresh and dry weights of seedlings have a direct relationship with thousand seed weight according to the earlier studies. Weight of seed and seed germination percentage have a positive relationship and thus lower weight seeds cause to produce weaker seedlings (Tabasi et al., 2011)

According to the studies of George (2009) seed quality parameters such as 1000 seed weight, seed germination percentage, seed viability and seedling vigour have a direct influence on plant health and vigour throughout the crop duration. If seeds are of high vigour, then it shows higher germination percentage and helps to reduce seed rate. Therefore, to reduce the high seed cost, there is a possibility to produce high quality seeds with higher germination percentage.

Fruit size and fruit number determine the yield of tomato (Bertin et al., 2003). Even though it has found that plant hormones are regulating this event, source - sink relationship is apparently the major determinant of the final fruit yield. Studies have shown that, the relationship between source and sink of tomato plants might be varied with light penetration through the canopy, plant density of the particular field and its genetic make-up. Hence agronomic practices such as leaf removal is followed to manipulate source - sink relationship mainly through modified leaf area index (LAI). LAI in tomato is influenced by stem density, number of leaves on a stem and individual leaf size (Heuvelink, 1996). In earlier work done in this regard, removal of young leaves have shown positive effects on dry matter partitioning towards the fruits, while maintaining LAI at a sufficiently higher level (Xiao et al., 2004). As the number of fruits in a cluster has to share the photosynthate, the reserves for seeds are distributed among all the fruits in the plant when the source is limited, equal distribution of photosynthate causes to underdevelopment of fruits. It reduces the size of fruit, seed size and also the seed quality. As the harvesting progresses, plant vigour is also reduced resulting decline in seed vigour and seed reserves leading to deterioration of seed quality.

Usually, two to ten flowers could be found in one flower cluster of tomato. Proper pollination causes to transform 8 flowers into fruits on an average. However, this level of heavy bearing decreases the ultimate fruit quality of the harvest due to misshaping, formation of small fruits and uneven ripening. This is often seen in cultivars having large fruits. Therefore, to regulate fruit size and other related quality attributes, tomato clusters are pruned in order to maintain a lower number of fruits per cluster. It is essentially done in controlled environment agriculture (CEA). As a rule of thumb, in cultivars having larger fruits, clusters should be thinned to $3-4$ fruits and it is practiced once a week. Pruning should be practiced in tomato at regular intervals for maintaining a well balance between the 
plant growth and fruit production. Pruning and other training practices should be done in weekly intervals. Most indeterminate type tomatoes are pruned in to a single stem in CEA. Inappropriate pruning may result weak stems with heavy loads of irregular sized and shaped fruits. Fruit maturity also becomes unequal under this situation, thus making the harvesting difficult (Anon, 2010).

In the present study, the conventional method of canopy management i.e. no pruning of leaves and fruits with two other treatments; fruit cluster pruning and canopy management, have been compared at field level to find out the best method to produce high quality seeds. The study was also used to find out whether the yield of tomato could be increased significantly by canopy management.

\section{MATERIALS AND METHODS}

The field trial was conducted during Maha season, 2012/13 at the Horticultural Crop Research and Development Institute (HoRDI), Gannoruwa, Peradeniya (Mid country Wet zone) which is geographically situated at $7^{\circ} 16^{\prime} 60 \mathrm{~N}$ latitude and $80^{\circ} 34^{\prime} 60 \mathrm{E}$ longitude with an altitude of 592 meters. Existing soil type is Red Yellow Podzolic. The mean annual temperature is around $24.5^{\circ} \mathrm{C}$. Tomato, variety Thilina was used in a RCBD experiment with four replicates.

Seeds were sown in nursery and kept for a 2 week period. Nursery management, field establishment, pest and disease controlling and fertilizer application (both basal and top dressing) were carried out according to the recommendations of the Department of Agriculture (DoA), Sri Lanka. Healthy, uniform two week old seedlings were transplanted at a spacing of $80 \times 50 \mathrm{~cm}$ to maintain 15 plants per one plot on raised beds of $2.4 \times 2.5 \mathrm{~m}$. Staking was done to support plants and weeding and irrigation were done at regular intervals. The treatments employed were; Treatment 01: NP (Control) Normal procedure of growing tomato in the open field where canopy management and fruit cluster thinning were not practiced, Treatment 02: 5, 2P: All partial shoots of the plants were removed, except the main stem and fruit thinning was practiced to maintain 5 fruit clusters per plant, each having 2 fruits per cluster, Treatment 03: 5, 5P: All partial shoots of the plants were removed, except the main stem and fruit thinning was practiced to maintain 5 fruit clusters per plant, each having 5 fruits per cluster

In treatments 02 and 03, all partial shoots of the plants were removed, except the main stem to maintain the canopy. Unusually small fruits were removed after careful observations. There were twelve plots and fifteen plants were maintained in each plot. For data recording five plants were selected randomly from each plot and numbered and tagged with yellow ribbons and were used to obtain fruits to find out the effect of treatments over seed quality. Another two plants from each plot were selected and tagged separately with blue ribbons in order to obtain fruits to find out the effect of treatments over yield increase.

Data were collected at physiological maturity (ripen) stage of fruits from selected sampling plants in each plot. Seed extraction was done using wet method. Extracted seeds were dried as per recommendation and analyzed for seed yield/plant, seed yield/fruit, germination $\%$, seed viability, seedling vigour (seedling shoot length, seedling root length and seedling fresh weight) and thousand seed weight at each harvest. Seed viability (200 seeds per treatment) was measured using the Tetrazolium test at 4 weeks after harvest. 
Germination percentage (400 seeds per treatment) was observed at 2 weeks after harvesting using standard method practiced at the seed laboratory, Gannoruwa and number of normal seedlings was counted at seventh and fourteenth day after seeding. Seedling shoot length, seedling root length and seedling fresh weights were measured using 20 randomly selected normal seedlings at seventh day after seeding. Seedling length was measured from the shoot tip to base of the root using a ruler and seedling fresh weight and thousand seed weight was measured using a top loading balance.

Descriptive statistics of the tomato fruit and seedling data were calculated and the normality of each parameter was tested using the Univariate procedure of SAS version 9.1 (SAS Institute, 2009). The effect of canopy management and cluster pruning was statistically analyzed by using GLM procedure in SAS considering the pick number, treatment and the block as the independent variables and fruit or seedling measurements as the dependent variables. The least square means (LS means) were calculated for mean separation.

\section{RESULTS AND DISCUSSION}

\section{Fruit weight}

Fruits were harvested weekly from January 08 to March 25, 2013 in six harvests. During first two weeks of harvest, the mean fruit weight was significantly different among treatments where it was $57.7 \mathrm{~g}$ in plants subjected to NP while it was $68.1 \mathrm{~g}$ and $73.6 \mathrm{~g}$ respectively, in plants subjected to two levels of pruning. In the other four weeks of harvesting, the plants from 5, $2 \mathrm{P}$ method provided significantly highest fruit weight than the fruits obtained from plants subjected to NP or 5, 5 P methods $(P<0.05)$ (Table 1$)$. The results for fruit weight clearly demonstrated that the 5, $\mathbf{2} \mathbf{P}$ canopy management method produced larger fruits compared to the fruits produced by plants subjected to NP or 5, $\mathbf{5}$ P canopy management methods.

Table 1. Fruit weight for three canopy management methods

\begin{tabular}{lcccccc}
\hline \multirow{2}{*}{ Management method } & \multicolumn{6}{c}{ Fruit weight (g) at each harvest } \\
\cline { 2 - 7 } & $\mathbf{1}$ & $\mathbf{2}$ & $\mathbf{3}$ & $\mathbf{4}$ & $\mathbf{5}$ & $\mathbf{6}$ \\
\hline $\mathrm{NP}$ & $57.7^{\mathrm{b}}$ & $56.5^{\mathrm{b}}$ & $58.3^{\mathrm{b}}$ & $53.0^{\mathrm{b}}$ & $43.9^{\mathrm{c}}$ & $37.5^{\mathrm{c}}$ \\
$5,2 \mathrm{P}$ & $68.1^{\mathrm{a}}$ & $71.7^{\mathrm{a}}$ & $79.9^{\mathrm{a}}$ & $66.1^{\mathrm{a}}$ & $82.6^{\mathrm{a}}$ & $55.1^{\mathrm{a}}$ \\
$5,5 \mathrm{P}$ & $73.6^{\mathrm{a}}$ & $65.1^{\mathrm{a}}$ & $58.9^{\mathrm{b}}$ & $52.4^{\mathrm{b}}$ & $60.6^{\mathrm{b}}$ & $48.1^{\mathrm{b}}$ \\
\hline
\end{tabular}

Fruits were harvested weekly in the period from January 08, 2013 to March 25, 2013.

Means followed by the same letter (in superscripts) within the column are not significantly different at $P<0.05$

\section{Seed weight}

Thousand seed weight of three canopy management and fruit thinning methods was compared. Seeds from the control plants (NP) were lighter (2.4 g per 1000 seeds) than seeds from 5, $2 \mathrm{P}$ plants and 5, $5 \mathrm{P}$ plants (2.7 $\mathrm{g}$ and $2.6 \mathrm{~g}$ per $1000 \mathrm{seeds}$, respectively). However, the difference between 5, $2 \mathbf{P}$ and 5, $5 \mathbf{P}$ was not significantly different $(P<0.05)$. With respect to the seed weight, canopy management and fruit thinning increased the seed weight compared to no pruning, indicating the usefulness of the fruit thinning (Table 2). 
Table 2. Weight of 1000 seeds for three canopy and fruit management methods

\begin{tabular}{lc}
\hline Management method & 1000 seed weight $(\mathbf{g})$ \\
\hline $\mathrm{NP}$ & $2.4^{\mathrm{b}}$ \\
$5,2 \mathrm{P}$ & $2.6^{\mathrm{a}}$ \\
$5,5 \mathrm{P}$ & $2.6^{\mathrm{a}}$ \\
\hline
\end{tabular}

Means followed by the same letter (in superscripts) within the column are not significantly different at $P<0.05$

The 1000 seed weight at the different weeks of harvesting was also compared. Due to practical reasons, seeds from harvests one and two were pooled together and seeds of harvests five and six were also pooled together for seed analysis. As shown in Table 3, time of fruit harvesting had a significant effect on the 1000 seed weight. Early harvesting yielded higher seed weight (2.96 g and $2.72 \mathrm{~g}$ ) compared to seeds of late harvesting ( $2.25 \mathrm{~g}$ and 2.24 $\mathrm{g}$ ). This implied that quality seeds could be extracted from the fruits of early harvesting (first 3 picks) than the seeds extracted later in the season.

Table 3. Weight of 1000 seeds over harvest number

\begin{tabular}{lc}
\hline Harvest Number & 1000 seed weight $(\mathbf{g})$ \\
\hline $1+2$ & $2.96^{\mathrm{a}}$ \\
3 & $2.72^{\mathrm{a}}$ \\
4 & $2.25^{\mathrm{b}}$ \\
$5+6$ & $2.24^{\mathrm{b}}$ \\
\hline Means followed by the same letter (in superscripts) within the column are not significantly different at $P<0.05$
\end{tabular}

\section{Seed purity}

The inert matter content in the seed lot was not significantly different (data no shown) for three canopy management and cluster pruning methods $(P<0.05)$. This implied the inert mater content in this seeds is not related to plant management and it could be related to seed processing.

\section{Seed germination}

The number of germinated seeds, number of non germinated seeds and number of dead seeds were counted in equally large samples. Control treatment, NP, recorded the highest germination percentage that was not significantly different from 5, 5 P method. However, the treatment 5, $2 \mathrm{P}$ registered lowest percent germination compared to other two treatments. Number of non-germinated seeds was lowest in NP method (24.0 seeds) while that was 30.3 and 26.0 seeds, respectively in 5, $2 \mathbf{P}$ and 5, $5 \mathbf{P}$ treatments (Table 4).

Table 4. Number of seeds germinated, number of fresh seeds and number of dead seeds from three canopy management methods

\begin{tabular}{lccc}
\hline $\begin{array}{l}\text { Management } \\
\text { method }\end{array}$ & $\begin{array}{c}\text { Number of } \\
\text { germinated seeds }\end{array}$ & $\begin{array}{c}\text { Number of fresh seeds } \\
\text { after germination }\end{array}$ & $\begin{array}{c}\text { Number of dead seeds } \\
\text { after germination }\end{array}$ \\
\hline NP & $73.2^{\mathrm{a}}$ & $23.9^{\mathrm{b}}$ & $2.4^{\mathrm{a}}$ \\
$5,2 \mathrm{P}$ & $66.5^{\mathrm{b}}$ & $30.3^{\mathrm{a}}$ & $2.6^{\mathrm{a}}$ \\
$5,5 \mathrm{P}$ & $71.9^{\mathrm{a}}$ & $26.0^{\mathrm{a}}$ & $2.0^{\mathrm{a}}$ \\
\hline Means followed by the & & $0^{\mathrm{a}}$ &
\end{tabular}


The above results suggested that the fruit thinning has no significant effect on seed germination.

Early or late harvesting of fruits had inconclusive relationships to the percent seed germination (Table 5). It seems that early or late harvesting of fruits has no direct relationship with seed germination. However, third harvest produced seeds with least germination percentage, the highest number of fresh seeds and the highest number of dead seeds after germination (Table 5).

Table 5. Number of seeds germinated, number of fresh seeds and number of dead seeds over of fruits from harvesting times

\begin{tabular}{|c|c|c|c|}
\hline Harvest Number & $\begin{array}{c}\text { Number of } \\
\text { germinated seeds }\end{array}$ & $\begin{array}{c}\text { Number of fresh } \\
\text { seeds after } \\
\text { germination } \\
\end{array}$ & $\begin{array}{l}\text { Number of dead seeds } \\
\text { after germination }\end{array}$ \\
\hline $1+2^{x}$ & $74.1^{\mathrm{a}}$ & $23.1^{\mathrm{b}}$ & $2.1^{\mathrm{b}}$ \\
\hline 3 & $59.2^{\mathrm{b}}$ & $36.5^{\mathrm{a}}$ & $4.2^{\mathrm{a}}$ \\
\hline 4 & $77.2^{\mathrm{a}}$ & $21.1^{\mathrm{b}}$ & $1.2^{\mathrm{c}}$ \\
\hline $5+6^{x}$ & $71.8^{\mathrm{a}}$ & $26.4^{\mathrm{b}}$ & $1.9^{\mathrm{b}}$ \\
\hline
\end{tabular}

\section{Seed viability}

Seed viability $(99.5 \%)(P<0.05)$ was significantly higher in. 5, $5 \mathbf{P}$ compared to other 2 treatments $(96.5 \%$ for NP and $96.0 \%$ for $\mathbf{5 , 2} \mathbf{P})$ those were not significantly different (Table $6)$.

Table 6. Percentage viability of seeds extracted from fruits of three canopy management methods

\begin{tabular}{lc}
\hline Management method & Percentage viability \\
\hline NP & $96.50^{\mathrm{b}}$ \\
$5,2 \mathrm{P}$ & $96.00^{\mathrm{b}}$ \\
$5,5 \mathrm{P}$ & $99.50^{\mathrm{a}}$ \\
\hline
\end{tabular}

Means followed by the same letter (in superscripts) within the column are not significantly different at $P<0.05$

\section{Seedling vigour}

Seedling vigour was assessed using, shoot length and root length of seedlings and the weight of seedlings. The significantly higher shoot length was observed in 5, $\mathbf{2} \mathbf{P}$ seedlings (5.70 $\mathrm{cm})$ compared to $\mathbf{N P}(5.40 \mathrm{~cm})$ and $\mathbf{5 , 5} \mathbf{P}(5.47 \mathrm{~cm})$ seedlings. However, shoot length was not significantly different between treatments. The significantly higher root lengths were observed in 5, $2 \mathbf{P}(5.20 \mathrm{~cm})$ or 5, $5 \mathbf{P}(5.16 \mathrm{~cm})$ seedlings. The seedlings with respect to NP treatment recorded significantly lowest root length $(4.84 \mathrm{~cm})$. Weight of the seedlings showed the same pattern as in root length where highest seedling weight was observed in $\mathbf{5 , 2}$ $\mathbf{P}$ and 5, 5 P (0.77 and $0.75 \mathrm{~g}$ per 20 seedlings) while that was least in NP plants $(0.64 \mathrm{~g})$ 
(Table 7). These results clearly demonstrated that the canopy management and fruit thinning had significant effect on seedling vigour.

Table 7. Comparison of seedling vigour with reference to canopy management methods

\begin{tabular}{lccc}
\hline $\begin{array}{l}\text { Management } \\
\text { method }\end{array}$ & $\begin{array}{c}\text { Shoot length of seedling } \\
(\mathbf{c m})\end{array}$ & $\begin{array}{c}\text { Root length of seedling } \\
(\mathbf{c m})\end{array}$ & $\begin{array}{c}\text { Weight of 20 seedlings } \\
(\mathbf{g})\end{array}$ \\
\hline NP & $5.40^{\mathrm{b}}$ & $4.84^{\mathrm{b}}$ & $0.64^{\mathrm{b}}$ \\
$5,2 \mathrm{P}$ & $5.70^{\mathrm{a}}$ & $5.20^{\mathrm{a}}$ & $0.77^{\mathrm{a}}$ \\
$5,5 \mathrm{P}$ & $5.47^{\mathrm{b}}$ & $5.16^{\mathrm{a}}$ & $0.75^{\mathrm{a}}$ \\
\hline
\end{tabular}

Means followed by the same letter (in superscripts) within the column are not significantly different at $P<0.05$

The seedling vigour was also compared among the different times of harvest (Table 8). Two early harvesting $(1+2$ and 3$)$ provided significantly higher shoot and root lengths of seedlings and weight of 20 seedlings compared to the late harvesting ( 4 and 5+6). Therefore, it is safe to recommend that seeds should be extracted from early harvested fruits to achieve the highest seedling vigour.

Table 8. Comparison of seedling vigour during each harvest

\begin{tabular}{lccc}
\hline $\begin{array}{l}\text { Harvest } \\
\text { Number }\end{array}$ & $\begin{array}{c}\text { Shoot length of } \\
\text { seedling }(\mathbf{c m})\end{array}$ & $\begin{array}{c}\text { Root length of seedling } \\
(\mathbf{c m})\end{array}$ & $\begin{array}{c}\text { Weight of 20 } \\
\text { seedlings }(\mathbf{g})\end{array}$ \\
\hline $1+2^{*}$ & $6.07^{\mathrm{a}}$ & $5.59^{\mathrm{a}}$ & $0.77^{\mathrm{b}}$ \\
3 & $6.24^{\mathrm{a}}$ & $5.93^{\mathrm{a}}$ & $0.89^{\mathrm{a}}$ \\
4 & $4.96^{\mathrm{b}}$ & $4.38^{\mathrm{b}}$ & $0.65^{\mathrm{c}}$ \\
$5+6^{*}$ & $4.82^{\mathrm{b}}$ & $4.37^{\mathrm{b}}$ & $0.57^{\mathrm{d}}$ \\
\hline
\end{tabular}

${ }^{*}$ Due to the limited availability of seeds in weeks 1,2,5 and 6, seeds extracted from weeks 1,2 and 3,4 were pooled together separately.

Means followed by the same letter (in superscripts) within the column are not significantly different at $P<0.05$

Subsistence vegetable farming practices in Sri Lanka usually relies on the farmer saved seeds (FAO, 2009). Therefore, the germination percentage of a seed lot is important as a low quality seed lot increases the seed rate which in turn incurred high seed cost to the farmer.

The results revealed that, 5, 2 P method (all partial shoots of the plants were removed, except the main stem and fruit thinning was practiced to maintain 5 fruit clusters per plant, each having 2 fruits per cluster) is the best practice to obtain high quality seeds for tomato cultivation. The results of the study are in agreement with Tabasi et al., (2011) as seed germination percentage is not affected by fruit thinning and canopy management. However, dry matter partitioning is changed dramatically making high quality seeds in tomato fruits of pruned plants. Treatment 5, 2 P produced significantly highest fruit weight with desirable size (Table 1). The reason behind that is the capability of leaves to produce more assimilates. Hesami et al., (2012) reported that, according to the studies conducted by Arzani et al., (2000) fruits are powerful sink for carbohydrates, till end of the growing season and increase of volume depend on fruit number. Hence, fruit thinning at the initial stage can improve the size of the remaining fruits. In addition, it leads to more assimilates allocation to fruits and improves the fruit size and their quality. 
According to FAO (2009) seed vigour is defined as the ability of a seed to emerge from the soil and survive under potentially stressful field conditions and to grow rapidly under favourable conditions. Thus seed vigour is a vital feature of a seed lot and it finally results healthy seedlings for planting purpose. The results of this study revealed that, canopy management and fruit thinning has a great influence on seedling vigour. Studies done on tomato fruit quality by Hesami et al. (2012) showed that pruning of tomato could be practiced to increase the quality of tomato. Our results are also in agreement with those results. However, it is recommended to repeat the experiments using other important tomato varieties in Sri Lanka before making a general conclusion.

\section{CONCLUSION}

Canopy management and fruit thinning significantly improve the seed quality of tomato, especially in terms of seed weight. The seed viability and germination is not much enhanced by pruning as well as time of harvesting. However, seedling vigour is greatly enhanced by canopy management and fruit thinning leading to a rapidly growing seedling, particularly from the seeds obtained from plants maintained with five clusters and 2 fruits in each cluster ( 5, 2 P). For greater seedling vigour, it is advisable to limit to early harvesting ( $1-3$ picks) for seed purpose.

\section{REFERENCES}

Anonymous (2010). AgStat, Pocket Book of Agricultural Statistics. Department of Agriculture, Peradeniya: Sri Lanka.

Anonymous (2004). International Rules for Seed Testing, 2004 Edition, International Seed Testing Association, Bassersdorf, Switzerland.

Anonymous (2010). Tomato Research Report, University of Florida, Institute of Food and Agricultural Sciences (IFAS), Florida Agricultural Experiment Station, Office of the Dean for Research, Gainesville, FL 32611-020 Available online (http://edis.ifas.ufl.edu/cv266 Tomato Hand Book) [Accessed on 15.07.2013]

Bertin, N., Genard, M. and Fishman, S. (2003). A Model for an Early Stage of Tomato Fruit Development Cell Multiplication and Cessation of the Cell Proliferative Activity. Annuals of Botany. 92, 65-72.

FAO Hand book (2009). FAO, Seeds in Emergencies: A Technical Handbook: Available online (http://www.fao.org/docrep/014/i1816e/i1816e00.pdf) [Accessed on 15.07.2013]

George, R.A.T. (2009). Vegetable Seed Production. CABI Publishing [on line] [Accessed on 10.07.2013].

http://bookshop.cabi.org/Uploads/Books/PDF/9781845935214/9781845935214.pdf

Heuvelink, E. 1996. Tomato growth and yield: quantitative analysis and synthesis. Dissertation, Wageningen Agricultural University, Wageningen, The Netherlands. 
Hesami, A., Sarikhani Khorami S., Hosseini, S.S. (2012). Effect of Shoot Pruning and Flower Thinning on Quality and Quantity of Semi-Determinate Tomato (Lycopersicon esculentum Mill.) Print ISSN 2067-3205; Electronic 2067-3264: Not Sci Biol, 2012, 4(1):108-111 Available online (www.notulaebiologicae.ronotulae scientia biologicae) [Accessed on 15.07.2013]

Tabasi, A., Nemati, H., Tehranifar, A. and Akbari, M. (2011). The Effects of Shrub Pruning and Fruit Thinning on Seed Germination and Seedling of Tomato in the Next Generation (Lycopersicon esculentum Mill). J. Biol. Environ. Sci. 5, 105-110.

Web resourses: http://agritech.tnau.ac.in/seed_certification/seed_veg_tomato.html [online] Tamilnadu Agricultural University web site [on line] [Accessed on 10.07.2013]

Xiao, S., Van der Ploeg, A., Bakker, M., et al., 2004. Two Instead of Three Leaves between Tomato Trusses: Measured and Simulated Effects on Partitioning and Yield. Acta Horticulturae, 654, 303-308. 